\title{
Bilingualism and Linguistic Influence in Nigeria: Examples from the Works of Achebe and Emecheta
}

\author{
Uriel Okunrinmeta ${ }^{1}$ \\ ${ }^{1}$ Department of English Studies, Adekunle Ajasin University, Ondo State, Nigeria \\ Correspondence: Uriel Okunrinmeta, Department of English Studies, Adekunle Ajasin University, PMB 001, \\ Akungba-Akoko, Ondo State, Nigeria. E-mail: urielok3@yahoo.com
}

\author{
Received: April 16, 2013 Accepted: May 22, 2013 Online Published: July 17, 2013 \\ doi:10.5539/ijel.v3n4p117 URL: http://dx.doi.org/10.5539/ijel.v3n4p117
}

\begin{abstract}
The present study explores the mutual influence that English and the Nigerian languages have on each other and demonstrates how Nigerian literary writers have succeeded in effectively capturing this in their works. The study, after analyzing Achebe's No Longer at Ease and Anthills of the Savannah, and Emecheta's The Joys of Motherhood with reference to borrowing, code-mixing and code-switching, coinages, semantic changes and peculiar Nigerian structures/expressions, reveals that the languages mutually influence each other since they exist side by side in the lives and tongues of Nigerians. The study also reveals that such Nigerian expressions as "lifu", "bubas", "eat bribe", "been-to", "not on seat", "bottom power", "owner's corner", "August break", "son of the soil", "after-bride palmwine", "chief wife", "aso-ebi cloth" and "you may laugh if laughter catches you", among several others, are manifestations of this mutual influence in the speech and writing of Nigerians. Their occurrence in the works of Achebe and Emecheta, therefore, indicates that they, as literary writers, are conversant with happenings in the Nigerian linguistic scene. Thus, the study shows that Nigerians are creative in the use of language since they are able to tap their bilingual experiences to adapt the languages at their disposal to suit the numerous conveniences, experiences, nuances and sensibilities in the Nigerian environment. The study also shows that this mutual influence, which has resulted in several peculiar Nigerian usages, has contributed immensely to the effective reflection and expression of the Nigerian experience and should, therefore, be seen as a good sign of healthy co-existence between English and the Nigerian languages in Nigeria's multilingual setting.
\end{abstract}

Keywords: bilingualism, linguistic, influence, Nigeria

\section{Introduction}

Bilingualism is a language phenomenon in which an individual functions with varying degrees of competence in at least two languages. According to Bloomfield (1935, p. 56), bilingualism describes "the native-like control of two languages." In contrast to Bloomfield's definition, Macnamara (1967) proposes that a bilingual is anyone who possesses a minimal competence in one of the four language skills, that is, listening comprehension, speaking, reading and writing in a language other than the mother tongue. These definitions, which range from a native-like competence in two languages to a minimal proficiency in a second language, reflect the various interpretations given to the term "bilingualism". In an attempt to facilitate better understanding of the psychological state of the individual who uses more than one language as well as two or more codes in interpersonal and intergroup relations, Hamers and Blanc $(1989$, p. 6) make a distinction between what they call "bilinguality" and bilingualism:

Bilinguality is the psychological state of an individual who has access to more than one linguistic code as a means of social communication ... The concept of bilingualism, on the other hand, includes that of bilinguality (or individual bilingualism) but refers equally to the state of a linguistic community in which two languages are in contact with the result that two codes can be used in the same interaction and that a number of individuals are bilingual (societal bilingualism).

They also propose various dimensions of bilinguality on the basis of which different types of bilinguals can be distinguished (Hamers \& Blanc, 1989, p. 8). The first distinction, which is based on the dimension of competence, has to do with the "balanced bilingual" (who has equivalent competence in both languages), and the "dominant bilingual" (whose competence in one of the languages, more often the mother tongue, is superior to 
his/her competence in the other). The second distinction, which is based on the dimension of cognitive organization, involves the "compound bilingual" who uses the two languages as if they are sourced from the same reference point and, thus, is unable to, according to Dadzie (2004, p. 143), function effectively in either of the languages since both languages "are so integrated at a deep level of organization that one language is equated more or less with the other", and the "coordinate bilingual" who possesses the ability to function effectively in both languages since he/she is able to distinguish the systems of both languages and, thus, keeps them separate.. As Hamers and Blanc $(1989$, p. 8) suggest, a coordinate bilingual should not, because of his/her high degree of competence in both languages, be misinterpreted to be a balanced bilingual because, in the case of the latter, it is a question of the state of equilibrium reached by the levels of competence attained in the two languages as compared to monolingual competence. Thus, the competence of a balanced bilingual in both languages may be high or low depending on when the state of equilibrium is reached. Whereas, in the case of a coordinate bilingual, it is high and, thus, it is often described as "near-native" (Dadzie, 2004, p. 142). The third distinction, which is based on the age of acquisition, is between "childhood bilinguality", "adolescent bilinguality" and "adult bilinguality", which are bilingual experiences that occur at the childhood, adolescent and adulthood stages respectively. "Childhood bilinguality", (the bilingual experience which takes place at the same time as the general development of the child), can further be distinguished on the basis of whether the child acquires the two languages at the same time ("simultaneous early or infant bilinguality") or at different times ("consecutive childhood bilinguality"). "Simultaneous early or infant bilinguality" describes a situation where the child develops two mother tongues from the onset of language often through informal, unintentional learning. "Consecutive childhood bilinguality", on the other hand, occurs where the child acquires a second language early in childhood but after the basic linguistic acquisition of the mother tongue has been achieved, and this may occur either informally or through intentional learning. The fourth distinction is between "endogenous bilinguality" and "exogenous bilinguality" based on whether the speech communities of both languages are present in the child's environment or not. In an endogenous bilinguality situation, the language that is used as mother tongue in the community, (that is, the endogenous language), may or may not be used for institutional purposes. In the case of exogenous bilinguality, however, the language that is used as an official, institutionalized language has no speech community in the political entity using it officially and, thus, it is an exogenous language. The fifth distinction, which is based on cultural identity, is made between a "bicultural/monocultural bilingual", a "second-language acculturated bilingual" and a "deculturated bilingual" (Berry, 1980). A bicultural bilingual is the bilingual who identifies positively with the two cultural groups that speak his/her languages and is, therefore, recognized by each group as a member. However, a bilingual may identify culturally with one of the groups only and, thus, he/she remains a "monocultural bilingual". A second-language acculturated bilingual, on the other hand, is the bilingual who renounces the cultural identity of his/her mother-tongue group and adopts that of the second-language group. Finally, a bilingual becomes "deculturated" when he/she gives up his/her own cultural identity but, at the same time, fails to identify with the $\mathrm{L}_{2}$ cultural group.

Of special significance to our discussion of bilingualism in this study are the concepts of dominant bilingualism and consecutive (or sequential) bilingualism. This is so because, in Nigeria's multilingual setting where English and over 250 Nigerian languages are in contact, and where most Nigerian learners of English are expected to have possessed the knowledge of their respective MTs before being exposed to the English language which is usually learnt at school later in life (Adegbite, 2009, p. 75), it is expected that certain aspects of the Nigerian languages will interfere with corresponding aspects of the English that is learnt and used by Nigerians (Bamgbose, 1971, p. 41; Kirk-Greene, 1971, p. 141; Adekunle, 1979; Banjo, 2004 and Okunrinmeta, 2011). This is not to say, however, that English (the second language of the vast majority of Nigerians) does not have any influence on the Nigerian languages. As Weinreich (1963), Greenberg (1971) and Spencer (1971) observed, when languages are in contact, they naturally influence each other. Thus, English and the Nigerian languages are expected to mutually influence each other since they exist side by side in the lives and on the tongues of the Nigerians who use them (Bamgbose, 1971; Adetugbo, 1979 and Essien, 1995). The task of this study is to explore the mutual linguistic influence that English and the Nigerian languages have on each other in the Nigerian linguistic scene and demonstrate how Nigerian literary writers have succeeded in effectively capturing, in their works, this mutual influence in Nigeria's multilingual socio-cultural setting. To achieve this, Chinua Achebe's No Longer at Ease and Anthills of the Savannah, and Buchi Emecheta's The Joys of Motherhood are selected for analysis in the study. The data collected from the three selected texts are analyzed, under borrowing, code-mixing and code-switching, Nigerian lexical coinages, semantic changes and peculiar Nigerian structures/expressions, in relation to the linguistic influences documented in such studies on bilingualism in Nigeria as Bamgbose (1971), Kujore (1985), Adegbija (1989), Jowitt (1991), Akere (2004), Bamiro (2006a), (2006b) and Okunrinmeta (2006), (2009), (2011), among others, so as to confirm if the mutual linguistic 
influences reflected by Achebe and Emecheta in their works represent what actually happens in the Nigerian linguistic environment.

\section{Borrowing}

Borrowing is one of the commonest ways through which the mutual influence that the Nigerian languages and English have on each other is manifested. This occurs when the vocabulary of each of the languages in this contact situation witnesses an influx of items from the other. Though borrowing in the Nigerian situation is mutual since it is natural for each language to borrow from the other, Essien $(1995$, p. 271) observes that the traffic flows more heavily in the direction of the Nigerian languages, probably because of the higher technology, industrialization, education, military prowess etc. associated with English-speaking nations. Thus, there is large-scale influx of English items into the vocabulary of the Nigerian languages. Such English words as "street", "bread", "table", "meeting", "jigger", "dirty", "lawyer", "tailor", "alum", "technology" and "chief" are just a few of the numerous words in English that have found their ways into the vocabulary of the Nigerian languages. However, to ensure that these borrowed items conform to the patterns of the Nigerian languages, they have been modified thus: "titi" (street), "buredi" (bread), "tabili" (table), "mitini" (meeting), "jiga" (jigger), "doti” (dirty), "loya" (lawyer), "telo" (tailor), "alomu" (alum), "tekinoloji”" (technology) and "shiifu" (chief) (Bamgbose, 1995, p. 24 and Akere, 2004, p. 278). This notwithstanding, there are some borrowings from the vocabulary of the Nigerian languages into the English of Nigerian speakers: "kiakia", "tokunbo", "suya", "edikan ikon", "akamu", "danshiki", "oba", "eze", "juju", "egunje", "babalawo", "wahala", "mekunu” and "talakawa" just to mention a few (Kujore, 1985; Jowitt, 1991 and Igbanusi, 2001).

This is exactly what has been reflected by Achebe and Emecheta in their works. In No Longer at Ease and The Joys of Motherhood, for example, both Achebe and Emecheta reflect the influx of English items into the vocabulary of the Nigerian languages. Such words as "wrapper", "America", "sir" and "leave" are just a few of the numerous English words that have found their way into the vocabulary of the Nigerian languages. However, to ensure that these borrowed items conform to the patterns of the Nigerian languages, they have been modified as "lappa" for "wrapper", "Emelika" for "America", "sah" for "sir" and "lifu" for "leave" as illustrated in (1) (4) below:

(1) Her strength was unflagging. One or two early risers saw her, tried to stop her and ask where she was going. For they saw a young woman of twenty-five, with long hair not too tidily plaited and with no head-tie to cover it, wearing a loose house buba and a faded lappa to match tied tightly around her thin waist, and they guessed that all was far from well. (The Joys of Motherhood, 2).

Nnu Ego dried her tears and said primly, 'Oh, I haven't just got daughters, I have a son in "Emelika”, a boy in grammar school, and another who is going to be a farmer.' (The Joys of Motherhood, 252).

...'Good night, madam. Good night, sah', Nnaife said to the master, who was pretending to be too engrossed in the paper he held in front of him to be aware of what was going on about him. (The Joys of Motherhood, 41).

Although he had two weeks, he proposed to spend only one at home for reasons of money. To home people, leave meant the return of the village boy who had made good in the town, and everyone expected to share in his good fortune. 'After all', they argued, 'it was our prayers and our libations that did it for him.' They called leave lifu, meaning to squander. (No Longer at Ease, 114).

In (1), "wrapper", which is a piece of cloth (of about two yards or more) tied around the waist of women, covering the parts between the waist and the ankles, is pronounced by some speakers of Igbo and other Nigerian languages as "lappa" because of their inability to pronounce the $/ \mathrm{r} /$ appropriately in the word. According to Jowitt (1991, p. 80), there is confusion of /1/ and /r/ among less educated speakers of certain Nigerian languages, including Tiv, Idoma, Ebira and Onitsha Igbo, in which there is no phonemic distinction between the two. Thus, it is not surprising that the / $\mathrm{r} /$ in "wrapper" is pronounced as /1/ in "lappa" by such Nigerian speakers so as to ensure that the word conforms to the phonological pattern of their mother tongue. The same thing occurs in "Emelika" in (2) where the /r/ in "America" is pronounced as /1/. In (3), "sir" is pronounced as "sah" because of the difficulty the majority of Nigerians have with the pronunciation of the central vowel /3:/ thereby pronouncing it either as /J/, /a/ or /E/. As Jowitt (1991, p. 75) notes, /3:/ does not occur in any Nigerian language. Thus, there are several directions in which its realization can tend. It is realized as $/ \mathrm{J} /$ when its spelling correlate is "-ur-" or "-or-" (as in /kod/ for "curd" or /wod/ for "word"), and as /a/ or / $\varepsilon /$ when the correlate is "-ir-", "-ear-" or "-er-" (as in /sa/ for "sir", /had/ for "heard" or /pet/ for "perch"). Finally, in (4), "leave" is modified and pronounced as "lifu", not only to give an Igbo rendition to it, but also to associate with it the meaning that the Igbos give to the word "lifu" (to squander) so as to reflect the sense that when people go home to spend their 
annual leave, they often engage in extravagant spending since they are expected to cater for the needs of their relations during the period.

Both Achebe and Emecheta have also reflected in their works the borrowing of items from the vocabulary of the Nigerian languages, especially Yoruba and Igbo, into the English of Nigerian speakers. In The Joys of Motherhood, for example, we have such items as "buba" (short, loose garment with ample sleeves reaching the elbow, worn by men or women) (2), "chi" (a personal god that, as it is believed among the Igbos, gives one life and controls one's destiny, and must, therefore, be appeased at all times through sacrifices) (3), "iba" (the general name for fever among the Yorubas of South-western Nigeria) (21), "ogogoro" (locally distilled gin) (74), "iyawo" (a Yoruba word, meaning "new wife") (112) and "esusu" (a kind of savings among friends whereby each member of the group collects contributions in turn) (164) to demonstrate the convenience with which Nigerians co-opt these borrowed Nigerian lexical items into the English they speak. In No Longer at Ease, there are also such items as "akara" (small deep-fried cakes made of bean flour) (15), "egusi" (a type of melon-seed) (19), "agbada" (a large gown worn by men, often embroidered at the neck and cuffs and with flowing sleeves that can be hitched over the shoulders) (29) and "osu" (an outcast in Igbo land, who is dedicated to the gods and, thus, barred from mingling up with other people) (64). We also have in Anthills of the Savannah such words as "kabu kaboo" (a private car that is used for commercial purposes so as to cushion the biting effects of the poor economic conditions in Nigeria) (80), "garri" (cassava flour processed by filtering, drying and frying) (83), "ube" (pear) (94) and "koboko" (a stiff cowhide tail) (173), among others.

These borrowed items reflected in the works of Achebe and Emecheta testify to the mutual influence that English and the Nigerian languages have on each other in the Nigerian environment and, thus, a good sign of the healthy co-existence that exists between the languages in this contact situation.

\section{Code-Switching and Code-Mixing}

The mutual influence that English and the Nigerian languages have on each other in the Nigerian multilingual setting is also reflected through code-switching and code-mixing. Code-switching, according to Kachru (1978, p. 108), entails the ability to switch from code A to code B depending on the function, the situation and the participants, while code-mixing entails the transfer of linguistic units from one code into another thereby forming a new code of linguistic interaction. Bamiro (2006a, p. 24) views code-switching from a literary perspective to include those instances where a character in the text switches from code A to code B, while code-mixing entails those instances where there are lexical transfers from the author's native language into the mode of narration (English). Bamiro's description of code-mixing appears to be contrary to that of Ansre (1971, p. 147) who describes it as a situation whereby speakers who are bilingual in English and a West African language insert varying chunks of English into their performance of the West African language. Following Ansre's observation, Banjo (1986) and Bamgbose (1995) describe code-mixing in the Nigerian setting as the retention of the Nigerian language syntax and the insertion into it of English words or phrases. However, Okunrinmeta (2008, p. 44) notes that the positions of Ansre (1971), Banjo (1986) and Bamgbose (1995) on the one hand, and that of Bamiro (2006a) on the other, do not present the true picture of what happens in the Nigerian multilingual setting where Nigerians who are bilingual in English and a Nigerian language can, in the process of communication, insert English words or phrases into the structure of a Nigerian language sentence or insert Nigerian language words or phrases into English sentences especially when they cannot, because of the constraints the English language puts on the second-language user, easily and immediately find an appropriate word or expression in English for what they intend to say. Thus, it is possible for Nigerians, as we shall soon see in the works selected for the study, to switch from English to the Nigerian languages or vice versa, or to "insert varying chunks of English" into their performance of a Nigerian language and vice versa. This is the point that Achebe and Emecheta have proved in their works.

In the works of Achebe and Emecheta, numerous instances can be cited to demonstrate the occurrence of code-switching in the speech and writing of Nigerians and the various functions it performs as a significant aspect of the communicative process in Nigeria's multilingual environment. As Bamiro (2006a) notes, code-switching performs various pragmasociolinguistic functions in Nigeria's multilingual setting: a mark of identity, solidarity, region, exclusion from an in-group membership, status manipulation and social and communicative distance, among others (Essien, 1995 and Osoba, 2007). In Achebe's No Longer at Ease, for example, Clara switched from English to Igbo for the purpose of showing solidarity; to show that she and Obi are from the same ethnic group:

"I noticed you were not looking very well", she said in Ibo, "so I brought you some tablets of Avomine...But then she had spoken in Ibo, for the first time, as if to say, "We belong together: we speak 
the same language." And she had appeared to show some concern. (22-23).

Also, in No Longer at Ease, Clara switched from English to Pidgin to accommodate the third interactant, Samson, the steward of Sam the Minister:

(6) Obi told her ... say hello to Sam? ... "Wetin Master and Madam go drink? asked his steward. "Make you no worry, Samson. Just tell Minister say we call." "You go return again?" asked Samson. "Not today." "You say you no go drink small sometin?" "No, thank you. We go drink when we come again. Bye-bye." (85 - 86).

It is this same function of accommodation that Beatrice uses code-switching to perform in Anthills of the Savannah, where she switched from English to Pidgin to accommodate Sylvanus, Chris's cook, who speaks only Pidgin:

'Make I fix madame small sometin,' he pleaded... 'Or sometaim you wan go for hotel?'... 'No Sylvanus,' said Beatrice trying to mollify him, 'we no de go anywhere. We jus wan sidon for house. Make you take evening off. If at all oga wan anything I fit getam for am.' (64).

Similarly, in No Longer at Ease, Obi switched from English to Igbo in his conversation with Charles so as to shut Miss Tomlinson out of the discussion:

He sent for Charles and asked him in Ibo (so that Miss Tomlinson would not understand) why he had not fulfilled his promise. Charles scratched his head and renewed his promise, this time for the end of December. (88).

In Emecheta's works, just like those of Achebe, there are instances that demonstrate the occurrence of code-switching in Nigeria's multilingual setting. In The Joys of Motherhood, Nwakusor addressed Nnu Ego in Igbo to create a sense of oneness and brotherliness so as to persuade her from going further on her intended suicide mission:

Nwakusor, breathing heavily, gasped in Igbo, 'What are you trying to do to your husband, your father, your people and your son who is only a few weeks old? You want to kill yourself, eh? Who is going to look after your baby for you? You are shaming your womanhood, shaming your motherhood.' (64).

This paid off as she stopped struggling with Nwakusor to ponder on her situation and to think of how she could explain what had happened to him. The calm that followed gave another Igbo woman, who, because of the sense of oneness and brotherliness created by Nwakusor's switch to Igbo, felt she had a responsibility to save a fellow Igbo "sister", the opportunity to step forward to slap Nnu Ego thereby bringing her back to her senses and, thus, forcing her to speak up:

Another Ibo woman, carrying a large basket of yams on her way to the market, was not satisfied with Nwakusor's verbal chastisement. She stepped forward and slapped Nnu Ego on one side of her face ... Then Nnu Ego cried, put so much force into the use of her voice that the sound broke through ... 'But I am not a woman any more ... The child is there, dead on the mat. My chi has taken him away from me. I only want to go in there and meet here ...' (65).

If Nwakusor had not switched to Igbo, the woman wouldn't have known that Nnu Ego was an Igbo woman. Similarly, if the woman had not stepped forward to slap Nnu Ego, she (Nnu Ego) wouldn't have regained her voice to explain what had happened thereby eliciting the sympathy and support of the crowd.

Code-switching also performs an accommodation function in The Joys of Motherhood. After Nnu Ego had explained why she was trying to commit suicide by jumping into the Lagos Lagoon, the Igbo woman, who slapped Nnu Ego earlier, had to switch to Yoruba to explain what happened to the Yoruba crowd surrounding them thereby making it clearer to them why Nnu Ego had behaved in that strange manner. This had the effect of making the crowd to have sympathy on Nnu Ego, instead of blaming her as done earlier.

Similarly, Mrs Meers, a white mistress, addressed her servants (Nnaife and the others) in Pidgin because they could neither speak nor understand Standard English:

$$
\text { 'Naafi!' drawled Mrs Meers ... 'We de go back to England!' (91). }
$$

'No be dis week, but na week after next. Those them sheets, don't bother to iron them. Make you and your missus keep them.' (92).

The switch to Pidgin in these instances is to ensure that the servants are accommodated thereby enhancing effective communication between both participants.

Also, Adim, the second son of Nnaife, switched to Yoruba to ensure that the butcher and his family members 
(who do not understand Igbo) are promptly informed of Nnaife's plan to attack them and, thus, alerting them on the impending danger:

(13) His family could not hold him. He was so wild ... Adim somehow guessed where he was going ... He ran fast, jumping over a small bush that separated the butcher's house from their own. He went in there and shouted in Yoruba: 'Wake up, all of you, somebody is coming to kill your father. Wake up!' (236).

Both Achebe and Emecheta have also provided enough evidence to prove the occurrence of code-mixing in the speech and writing of Nigerians. In No Longer at Ease, for example, Achebe demonstrates the possibility of inserting English items into the structure of Igbo sentences as shown in the conversation between Obi and $\mathrm{Mr}$ Mark on how to assist his (Mr Mark's) sister:

Although he spoke in Ibo, there were some words that he had to say in English. Words like "School Certificate" and "Scholarship". (79).

There are also instances in No Longer at Ease where Achebe has demonstrated the possibility of inserting varying chunks of Igbo into an English sentence. Such Igbo items as "kpom-kwem" (a perfect example of something), "Ndo" (a form of greeting), "nza" (a bird) and "chi" (a personal god) have been inserted into the structure of the following English sentences:

(15) "Remark him", said Odogwu. "He is Ogbuefi Okonkwo come back. He is Okonkwo kpom-kwem, exact, perfect." (49).

(16) Everybody on arrival went to Obi and said 'Ndo' to him. (148).

(17) "He is a foolish somebody", said one of the men in English. "He is like the little bird $n z a$ who after a big meal so far forgot himself as to challenge his chi to single combat"... (148).

In Anthills of the Savannah, there are some instances in which Hausa, Igbo or Yoruba items are inserted into the structure of English sentences as shown in (18) - (20):

(18) For Mad Medico has a strange mania for graffiti which was the cause of all the wahalla that would have cost him his job and residence in the country about a year ago... (55). ("Wahalla" in Hausa means "problem").

(19) I ate my corn with $u b e$ and he his with $u b e$ and coconut in alternate mouthfuls. (95). ("Ube", a kind of fruit (pear) that is often eaten with corn, was taken from Igbo).

(20) At last she left the balcony and went indoors for a cold shower and then changed into a long, loose dress of blue adire embroidered in elaborate white patterns at the neck, chest, sleeves and hem. (110). ("Adire", which means "tie and dye", is a form of dress in Yoruba land).

Similarly, in The Joys of Motherhood, there are instances in which Yoruba or Igbo items are inserted into the structure of English sentences. These are illustrated in (21) - (23) below:

'Well, Oshia, you can't force people to invite you to their sarah.' But she sighed, knowing that sarahs were unofficial parties where food was free for all, especially children; they were usually given by women who wanted babies who were invariably told by the native doctors that the only way they would conceive was if they fed other children (110).

She had been attending classes at Mama Abby's, twice a week, before they moved. She could not cut complicated blouses yet, but she could stitch up their torn clothes and make the plain blouses known as bubas (212).

(23) Nnu Ego went back to Lagos and to the old routine of scraping, saving, counting every penny. Before, her refrain used to be: 'All will be well when Nnaife returns from the war.' Now it was: 'All will be well when Oshia returns from college.' Did not all the dibias consulted before he was born say that he was going to be a great man? (213).

"Sarahs", "bubas" and "dibias" are Nigerian language items inserted into the structure of English sentences and made to conform to the syntactic patterns of the English language. In (21) - (23) above, each of the inserted Nigerian language items occurs in its plural form through the addition of "-s" to the singular form "sarah" (110), "buba" (2) or "dibia" (143) respectively thereby reflecting one of the primary distinctive features of nouns in English: the ability to show a distinction between singular and plural. Apart from showing singular-plural distinction, the verb that follows each of the inserted items is in the plural form to indicate subject-verb agreement and, thus, enhancing the grammaticality of the structures in which the items occur.

These instances of code-switching and code-mixing highlighted above reflect the true picture of the Nigerian 
linguistic scene where Nigerians, who speak English and the Nigerian languages, switch from one to the other depending on various sociolinguistic factors, or insert English words or phrases into Nigerian language sentences and vice versa. Thus, it is what actually happens in Nigeria's multilingual setting where English and the Nigerian languages have mutual influence on each other that Achebe and Emecheta have accurately observed and reflected in their works.

\section{Nigerian Lexical Coinages}

Nigerians have, because of the contact between English and the Nigerian languages and culture in the Nigerian socio-cultural setting, manifested in their English usage some coinages that reflect the Nigerian socio-cultural experience. In the first place, they have, because of the quest for communicative appropriateness in English within the Nigerian socio-cultural context, coined new items from the existing lexical stock in English to appropriately reflect the Nigerian linguistic and socio-cultural situation. In No Longer at Ease, for example, we have such Nigerian expressions as "eat bribe" (31), "been-to" (84) and "head-ties" (128). Also, in Anthills of the Savannah, we have "pepper soup" (36), "not on seat" (43), "owner's corner" (72), "bottom power" (84), "August break" (94), "boys' quarters" (107), "second-hand clothes" (210), "sufferhead" (223) and "hot drink" (226). In The Joys of Motherhood, there are such Nigerian expressions as "sons of the soil" (6), "chief wife" (38), "a to-do" (41), "big mother" (82), "big man" (158) and "after-bride palmwine" (243). Similarly, Nigerians have coined some items through the mixture of existing lexical stock in English and the Nigerian languages. In The Joys of Motherhood, for example, we have "aso-ebi cloth" (25) and "kiakia bus" (59) (see also Kujore, 1985; Adegbija, 1989; Jowitt, 1991; Bamiro, 2006b and Okunrinmeta, 2009).

Let's now examine the meaning of each of these Nigerian coinages within the Nigerian socio-cultural context:

(24) eat bribe: a translation of the Yoruba expression "jẹ eguje”" (meaning, "eat bribe") and, thus, used instead of "take bribe".

(25) been-to: someone who has returned to Nigeria from a long stay overseas (see Jowitt, 1991: 160).

(26) head-tie: headgear or headdress. The analogy, "head-tie", is a consequence of the fact that this kind of costume involves "tying" a dress or cloth around the head (Bamiro, 2006b: 321). pepper soup: soup prepared with red pepper and other condiments to give it a hot and spicy flavour. not on seat: a translation of such expressions as "ko si ni ijoko" (Yoruba) or "pẹrẹi o fa" (Izon), often interpreted as "not in the office" or "not available" in the Nigerian context.

owner's corner: a corner in the back seat of a chauffeur-driven car, (at right angles to the chauffeur), reserved exclusively for the owner of the vehicle, the boss or a top-notch functionary in the public service or business circles.

bottom power: the influence which girls and women exert on men. This influence is usually made stronger through sexual intercourse. It is, therefore, referred to as "bottom power."

August break: the period during the rainy season when the rain stops temporarily, (perhaps for a month), before falling again. This period of break, which usually comes between early August and early September, is often characterized by a drizzly weather accompanied by heavy winds which dry the water up. The end of the "August break" is usually signalled by thunderblasts either by 12 noon or by 12 midnight, and these are often almost immediately followed by a heavy downpour.

boy's quarters: outhouses or living quarters, detached from the main house, for "house boys" and "house girls". ("House boy" or "house girl" is the Nigerian version of house keeper or servant).

second-hand clothes: second-hand is a translation of the Yoruba word "alokun", meaning, something that has already been used by another person. Thus, the term "second-hand clothes" in the Nigerian context refers to "fairly used clothes, sold to other people who wear them."

sufferhead: a luckless person.

hot drink: hard liquor such as whisky, gin and brandy.

son of the soil: a translation equivalent of the Yoruba expression, "omọ onilẹ", often used to refer to the free-born of a particular town or community.

chief wife: the most senior wife in a polygamous family whose major responsibility, in the family, is to guide and bring up her younger co-wives. 
(38) a to-do: a translation of "sise" (Yoruba) or "miyẹn iye" (Izon), which refers to a party or ceremony, including wedding or burial, that one is required to attend.

(39) big mother: the most senior wife in the family and, thus, all the children in the family have to call her "mother" or "big mother."

(40) big man: a wealthy and influential man; someone who is highly placed in society.

(41) after-bride palmwine: a translation of the Igbo expression, "nkwu ocha" or "nkwu elu", which refers to the kegs of palmwine paid by the family of the groom to that of the bride, especially when the bride is "found at home" (that is, she is a virgin) and also when she is well-behaved.

(42) aso-ebi cloth: a special cloth used in Yoruba land in such special ceremonies as wedding, burial, naming etc.

kiakia bus: "kia" in Yoruba means "quick". Thus, "kiakia bus" literally means a "quick quick bus" which does not waste much time on the way because, once it is loaded, it never stops until it reaches its destination.

The lexical coinages highlighted above, which occur in the works of Achebe and Emecheta to reflect their currency within the Nigerian socio-cultural environment, are translations or translation equivalents of items in the Nigerian languages and, thus, underscore the influence that the Nigerian languages have on the English of Nigerian speakers.

\section{Semantic Changes}

One of the manifestations of the influence of the Nigerian languages in the English of Nigerians is the restriction or extension of the meanings of some English words and expressions to accommodate the contexts which the Nigerian languages give to them in Nigeria's multilingual environment. The meanings of some English words and expressions have, because of the need for communicative appropriateness within the Nigerian context, been domesticated to reflect the meanings that their equivalents in the Nigerian languages express. The meaning of "borrow", for example, has been extended in the Nigerian context to cover the meaning of "lend" in the English of Nigerians. According to Okunrinmeta (2010, p. 159), this is traceable to the Nigerian languages where, unlike what obtains in English, there is no distinction between "borrow" (get something from somebody on the understanding that it is to be returned) and "lend" (give something to somebody on the understanding that it will be returned). The Izon word "bọlọi", for example, which is equivalent to "borrow" both in terms of "getting something from somebody for a period of time on the understanding that it will be returned or giving something to somebody for a period of time on the understanding that it will be returned", is used in such a way that it is interpreted to mean either "borrow" or "lend" depending on the context in which it is used. If you, for example, are the one giving out, you are "borrowing" (lending) the person that is receiving from you. But if you are the one receiving, you are "borrowing" from the person that is giving out e.g.

$$
\begin{array}{ccccccc}
\text { E } & \text { zụwa } & \text { ọkụba } & \text { kọ } & \mathrm{u} & \text { bolọi } & \text { tẹi. } \\
\text { I } & \text { some } & \text { money } & \text { for } & \text { him } & \text { borrow } & \text { PERF ASP NONPAST. }
\end{array}
$$

I have borrowed him some money.

$$
\begin{array}{ccccccc}
\text { E } & \text { u } & \text { o } & \text { zụwa } & \text { ọkuba } & \text { bolọi } & \text { tẹ̣. } \\
\text { I } & \text { him } & \text { from } & \text { some } & \text { money } & \text { borrow } & \text { PERF ASP NONPAST. }
\end{array}
$$

I have borrowed some money from him.

In (44), "bọlọi" has the meaning of "lend" because it is the speaker that is giving out. However, in (45), "bọlọi" is used in the sense of "borrow" since it is the speaker that is receiving from another person. It is this semantics of "bọlọi" in Izon, just like in all other Nigerian languages, that has been reflected in the English of Nigerians where "borrow" is used when somebody gives out or receives from another person. This is the sense in which "borrow" is used in No Longer at Ease in (46) below:

(46) Joshua Udo, a messenger in the Post Office, had been sacked for sleeping on duty. According to him, he had not been sleeping but thinking. But the Chief Clerk had been looking for a way to deal with him since he had not completed the payment of ten pounds' bribe which he had promised when he was employed. Joshua was now asking his countrymen to 'borrow' him ten pounds to look for another job (71).

However, as Okoro (2004, p. 177) observed, the use of "borrow" in the context of "lend", as illustrated in (46) above, is non-standard usage associated with Nigerians with low level of education and, thus, not common in 
educated Nigerian English. This explains why Achebe decides to reflect it in the English of Joshua Udo, a messenger in a Post Office.

\section{Peculiar Nigerian Structures / Expressions}

Nigerians have also manifested in their English some peculiar Nigerian structures and expressions which are, as a result of the local influences that English must accommodate so as to function effectively as a medium of interaction in Nigeria's multilingual setting, translated from the Nigerian languages. The peculiar Nigerian structures and expressions are illustrated in the works of Achebe and Emecheta in (47) - (51) below:

She smiled into space, and moved her lips in a quiet prayer: 'Please, God, let this child stay with me and fulfil all these my future hopes and joys.' (The Joys of Motherhood, 85).

The girls laughed. Obi had not changed a bit. He enjoyed teasing them, their mother not excepted. She smiled. 'You may laugh if laughter catches you', she said indulgently. 'It does not catch me.' (No Longer at Ease, 56).

'I am not going to listen to you any more. I take back my request. I shall start paying you back at the end of this month. Now, this minute! But don't you dare interfere in my affairs again. And if this is what you meet about', he said in Ibo, 'you may cut off my two legs if you ever find them here.' (No Longer at Ease, 75).

'... And I went and poured sand into your garri. I'm sorry, my dear.' (No Longer at Ease, 85).

The mosquito, which Chris repeatedly but unsuccessfully tried to swat with an old shirt he had brought to bed for the purpose, was taunting the ear in revenge for the insult with which his suit had once been rejected. (Anthills of the Savannah, 199).

In (47), there is the co-occurrence of the possessive and demonstrative determiners ("these" and "my") in the structure of the noun phrase "all these my future hopes and joys." According to Quirk et al. (2003, p. 254), "these" and "my" as central determiners are "mutually exclusive" and, thus, their co-occurrence in (47) where they follow each other in the noun phrase is not permitted in English. However, as observed by Okunrinmeta (2013), the co-occurrence of possessive and demonstrative determiners is allowed in the Nigerian languages. He cites the following examples from Izon to demonstrate this:

$\begin{array}{lccccc}\text { Ini } & \text { bei } & \text { zowei } & \text { bei } & \text { adị ebi } & \text { emi. } \\ \text { Your } & \text { DEM [MASC SG] } & \text { friend } & \text { DEM [MASC SG] } & \text { handsome } & \text { [BE] NONPAST. } \\ \text { Your this friend is handsome. } & & & \\ \text { Woni } & \text { u ma } & \text { abịrau } & m a & \text { bịra gụba } & \text { emi. } \\ \text { Our } & \text { DEM [FEM SG] } & \text { sister } & \text { DEM [FEM SG] } & \text { stingy } & \text { [BE] NONPAST. } \\ \text { Our that sister is stingy. } & & & & \end{array}$

Thus, what occurs in (47) above is a reflection of the preferred structural pattern in the Nigerian languages where possessive determiners are permitted to co-occur with demonstrative determiners in the structure of a noun phrase. It is this preferred pattern that has been transferred to the English of Nigerian speakers.

Similarly, in (48) and (49), there is a direct translation of an expression from the Nigerian languages in English. In (48), for example, "You may laugh if laughter catches you" is the direct translation of the Igbo expression "i nwere ike ichi ọchi ma ọchi tọo gi." The same is applicable in (49) where the Igbo expression, "i tu m ebe a ozọ, gbu jie m ukwu", is directly translated as "you may cut off my two legs if you ever find them here", which is often said in the Nigerian setting, especially when one's advice is turned down. In (50), there is the use of the local Nigerian idiom, "to pour sand into someone's garri", which means "to put someone into trouble", or "to implicate someone", or "to ruin someone's chances" (Okoro, 2004, p. 170). Finally, in (51), there is an allusion to the Nigerian folktale explaining the reason why the mosquito taunts the ear. According to Okunrinmeta (2009, p. 68), the folktale revolves round the love affair between the mosquito and the ear. The mosquito was in passionate love with the ear and, thus, it had to propose marriage to the ear. However, the ear turned down the mosquito's offer on the grounds that the mosquito had an uncertain future in the sense that the mosquito could, because of its light nature, be blown away to the sea by the breeze and make it perish there. The mosquito begged the ear to consider the proposal but the ear maintained that it would not marry the mosquito. Thus, the mosquito had no other option than to leave the ear alone. But before it left, the mosquito promised that whenever it came across the ear, it would remind the ear that it (the mosquito) was still alive and not dead. This is what the mosquito usually does whenever it comes close to the ear. It is, therefore, this folktale that was alluded to in the 
expression, "the mosquito ... was taunting the ear in revenge for the insult with which his suit had once been rejected", in (51) above.

All these Nigerian structures and expressions manifested in the English of Nigerian speakers and reflected in the works of Achebe and Emecheta are significant because they give a local Nigerian coloration to English usage in the Nigerian multilingual setting and, thus, demonstrate the influences that languages in contact often have on each other.

\section{Conclusion}

The objective of this study was to explore the mutual linguistic influence that English and the Nigerian languages have on each other in Nigeria's multilingual socio-cultural setting and demonstrate how Nigerian literary writers have succeeded in effectively capturing this mutual influence in their works. With reference to Chinua Achebe's No Longer at Ease and Anthills of the Savannah, and Buchi Emecheta's The Joys of Motherhood, the study has demonstrated that English and the Nigerian languages have mutual influence on each other in the Nigerian language contact situation and that the manifestation of this mutual linguistic influence is seen in terms of borrowing, code-switching and code-mixing, lexical coinages, semantic changes and peculiar Nigerian structures / expressions that are noticed in Nigeria's multilingual setting. This is exemplified by such Nigerian expressions as "lifu", "bubas", "eat bribe", "been-to", "not on seat", "bottom power", "owner's corner", "August break", "son of the soil", "after-bride palmwine", "chief wife", "aso-ebi cloth" and "you may laugh if laughter catches you", among several others, whose occurrence in the works of Achebe and Emecheta testifies to the fact that they, as literary writers, are conversant with happenings in the Nigerian linguistic scene. The study, therefore, shows that Nigerians are creative in the use of language since they are able to tap their bilingual / bicultural experiences in the Nigerian language-contact situation to adapt the languages at their disposal to suit the numerous conveniences, experiences, nuances and sensibilities in the Nigerian socio-cultural environment. The study also shows that the mutual influence in Nigeria's multilingual socio-cultural setting, which has resulted in several peculiar Nigerian usages, has contributed immensely to the effective reflection and expression of the Nigerian experience and should, therefore, be seen as a good sign of healthy co-existence between English and the Nigerian languages in Nigeria's multilingual socio-cultural setting.

\section{References}

Achebe, C. (1989). Anthills of the savannah. Ibadan: Heinemann.

Achebe, C. (2008). No longer at ease. London: Heinemann.

Adegbija, E. (1989). Lexico-semantic variation in Nigerian English. World Englishes, 8(2), 165-177. http://dx.doi.org/10.1111/j.1467-971X.1989.tb00652.x

Adegbite, W. (2009). The psycholinguistics of English language in Nigeria. Ibadan: Kraft Books.

Adekunle, M. A. (1979). Non-random variation in the Nigeria English. In E. Ubahakwe (Ed.), Varieties and functions of English in Nigeria (pp. 27-42). Ibadan: African Universities Press.

Adetugbo, A. (1979). Nigerian English and communicative competence. In E. Ubahakwe (Ed.), Varieties and functions of English in Nigeria (pp. 167-183). Ibadan: African Universities Press.

Akere, F. (2004). Nigerian English in sociolinguistic perspective: Users, uses and emerging varieties. In A. B. K. Dadzie, \& S. Awonusi (Eds.), Nigerian English: Influences and characteristics (pp. 256-284). Lagos: Concept Publications.

Ansre, G. (1971). The influence of English on West African languages. In J. Spencer (Ed.), The English language in West Africa (pp. 145-164). London: Longman.

Bamgbose, A. (1971). The English language in Nigeria. In J. Spencer (Ed.), The English language in West Africa (pp. 35-48). London: Longman.

Bamgbose, A. (1995). English in the Nigerian environment. In A. Bamgbose, A. Banjo, \& A. Thomas (Eds.), New Englishes: A West African perspective (pp. 9-26). Ibadan: Monsuro.

Bamiro, E. O. (2006a). The politics of code-switching: English vs. Nigerian languages. World Englishes, 25(1), 23-35. http://dx.doi.org/10.1111/j.0083-2919.2006.00445.x

Bamiro, E. O. (2006b). Nativization strategies: Nigerianisms at the intersection of ideology and gender in Achebe's fiction. World Englishes, 25(3/4), 315-328. http://dx.doi.org/10.1111/j.1467-971X.2006.00473.x

Banjo, A. (1986). The influence of English on the Yoruba language. In W. Viereck, \& W. D. Bald (Eds.), English in contact with other languages. Budapest: Akademiai Kiado. 
Banjo, A. (2004). A note on Yoruba/English bilinguals' phonological transfers. In S. Awonusi, \& E. A. Babalola (Eds.), The domestication of English in Nigeria: A festschrift in honour of Abiodun Adetugbo (pp. 15-19). Lagos: University of Lagos Press.

Berry, J. W. (1980). Acculturation as varieties of adaptation. In A. Padilla (Ed.), Acculturation: Theory and models. Washington: AAAS.

Bloomfield, L. (1935). Language. London: Allen and Unwin. http://dx.doi.org/10.2307/408842

Dadzie, A. B. K. (2004). Bilingualism. In A. B. K. Dadzie, \& S. Awonusi (Eds.), Nigerian English: Influences and characteristics (pp. 140-157). Lagos: Concept Publications.

Emecheta, B. (2008). The Joys of Motherhood. Edinburgh: Heinemann.

Essien, O. (1995). The English language and code-mixing: A case study of the phenomenon in Ibibio. In A. Bamgbose, A. Banjo, \& A. Thomas (Eds.), New Englishes: A West African perspective (pp. 269-283). Ibadan: Monsuro.

Greenberg, J. H. (1971). The study of language contact in Africa. Rpt. In A. S. Dil. (Ed.), Language, culture and communication: Essay by Joseph H. Greenberg (pp. 185-197). California: Stanford University Press.

Hamers, J. F., \& Blanc, M. H. A. (1989). Bilinguality and bilingualism. Cambridge: Cambridge University Press.

Igboanusi, H. (2001). A dictionary of Nigerian English. Ibadan: Sambooks Publishers.

Jowitt, D. (1991). Nigerian English usage: An introduction. Lagos: Longman.

Kachru, B. (1978). Code-mixing as a communicative strategy in India. In. J. E. Alatis (Ed.), Georgetown University round table on language and linguistics: International dimensions of bilingual education ( $\mathrm{pp}$. 107-124). Washington D.C.: Georgetown University Press.

Kirk-Greene, A. (1971). The influence of West African languages on English. In J. Spencer (Ed.), The English language in West Africa (pp. 123-144). London: Longman.

Kujore, O. (1985). English usage: Some notable Nigerian variations. Ibadan: Evans.

Macnamara, J. (1967). The bilingual's linguistic performance. Journal of Social Issues, 23, 58-77. http://dx.doi.org/10.1111/j.1540-4560.1967.tb00576.x

Okoro, O. (2004). Codifying Nigerian English: Some practical problems of labelling. In S. Awonusi, \& E. A. Babalola (Eds.), The domestication of English in Nigeria: A festschrift in honour of Abiodun Adetugbo (pp. 166-181). Lagos: University of Lagos Press.

Okunrinmeta, U. (2006). Beyond grammatical competence: The use of English in the Izon socio-cultural environment. UNAD Studies in Language and Literature, 2(1), 90-111.

Okunrinmeta, U. (2008). A linguistic approach to the meaning and functions of the town crier in Nigeria's multilingual setting. In B. L. Virtanen, \& S. Owonibi (Eds.), The mines of his mind: Critical reflections on the works of Tayo Olafioye (pp. 37-53). Trenton, NJ: Africa World Press.

Okunrinmeta, U. (2009). Some notable lexico-semantic variations in the English of Izon (Nigerian) speakers of English. Geolinguistics, 35, 55-74.

Okunrinmeta, U. (2010). The influence of Izon on the syntax and lexis of the English of Izon-English bilinguals. (Doctoral thesis). University of Lagos, Lagos, Nigeria.

Okunrinmeta, U. (2011). Izon syntax and the English of Izon-English bilinguals. World Englishes, 30(2), 211-228. http://dx.doi.org/10.1111/j.1467-971X.2011.01699.x

Okunrinmeta, U. (2013). Izon influences in Nigerian English syntax. English Language and Literature Studies, 3(2), 30-43. http://dx.doi.org/10.5539/ells.v3n2p30

Osoba, S. (2007). Some sociolinguistic functions of code switching. UNAD Studies in Language and Literature, 2(2), 13-21.

Quirk, R., Greebaum, S., Leech, G., \& Svartvik, J. (2003). A comprehensive grammar of the English language. London: Longman.

Spencer, J. (1971). West Africa and the English language. In J. Spencer (Ed.), The English language in West Africa (pp. 1-34). London: Longman.

Weinreich, U. (1963). Languages in contact: Findings and problems (2nd ed.). The Hague: Mouton. 


\section{Copyrights}

Copyright for this article is retained by the author(s), with first publication rights granted to the journal.

This is an open-access article distributed under the terms and conditions of the Creative Commons Attribution license (http://creativecommons.org/licenses/by/3.0/). 